\title{
Does brand-relationships matter? The role of brand attachment in salesperson performance in retailing
}

Does brandrelationships matter?

\author{
Flavia Braga Chinelato \\ CENTRUM Catolica Graduate Business School, Lima, Peru and \\ Pontificia Universidad Católica del Perú, Lima, Perú, and \\ Cid Gonçalves Filho and Clodoaldo Lopes Nizza Júnior \\ Fumec University, Belo Horizonte, Brazil
}

\begin{abstract}
Purpose - Salesperson performance is accepted as a relevant factor of retailing success. However, scarce studies reveal the relationship between sales performance and brand relationship. The purpose of this study is both, from one side, to empirically demonstrate the impact of salesperson brand attachment (SBA) on sales performance and, on the other side, to identify the mediators of this relationship in small retailing.

Design/methodology/approach - A survey was conducted with a sample of 206 small retailers from different sectors of an emerging country. The proposed model was tested using partial least squaresstructural equation modeling (PLS-SEM) in SmartPLS3.

Findings - The results demonstrated that SBA is relevant to driving sales performance through two relevant paths - one following SBA-satisfaction-performance and one path following the SBAcommitment-performance. The model was able to explain $63 \%$ of the outcome performance.

Practical implications - Regarding small retailers, where the owners, employees and managers have higher levels of interaction than the large national retail chains, the marketing executives must invest in improving the attachment to the brand and create emotional bonds and cognition between marketers and the brand. They must develop strategies to promote job satisfaction and organizational commitment because they determine performance.

Originality/value - Despite the relevance of small businesses for economies worldwide and the importance of salesperson brand relationships, no study has been developed to demonstrate the impacts of such relationships on salesperson performance in retailing. Furthermore, in addition to the central role of organizational commitment in the sales research, to the best of the authors' knowledge,
\end{abstract}

(C) Flavia Braga Chinelato, Cid Gonçalves Filho and Clodoaldo Lopes Nizza Júnior. Published in Spanish Journal of Marketing - ESIC. Published by Emerald Publishing Limited. This article is published under the Creative Commons Attribution (CC BY 4.0) licence. Anyone may reproduce, distribute, translate and create derivative works of this article (for both commercial and noncommercial purposes), subject to full attribution to the original publication and authors. The full terms of this licence may be seen at http://creativecommons.org/licences/by/4.0/legalcode

JEL classification - M0, M1, M30, M31, M39

The authors wish to thank the SJM-ESIC editor Carlos Flavian and the anonymous reviewers for their constructive reflections and comments to enable the publication of this paper.

The authors are grateful to FUMEC University/PROPIC for the financial support to this research, and to Minas Gerais State Agency for Research and Development - FAPEMIG for the scholarships that helped to make this research project feasible.
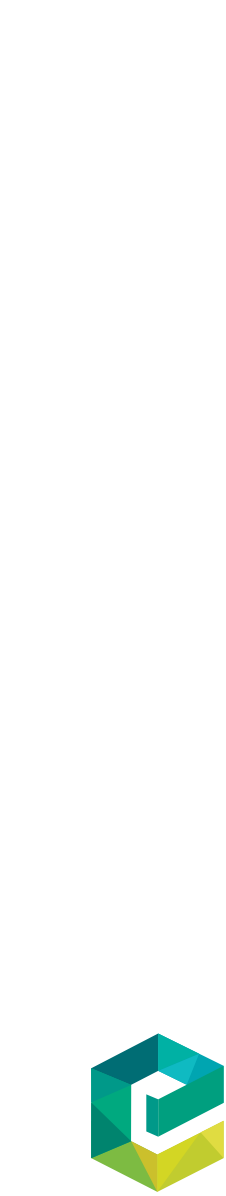
this is the first study to explore how to mediate the relationship between brand attachment and sales performance.

Keywords Retailing, Salesperson, Brand attachment, Organizational commitment, Job satisfaction, Sales performance, Small business

Paper type Research paper

\section{8}

¿Importa la relación con la marca? El rol del apego a la marca en el rendimiento del vendedor en el comercio minorista

\section{Resumen}

Propósito - El rendimiento del vendedor se acepta como un factor relevante para el éxito del comercio minorista. Sin embargo, los estudios que revelan la relación entre el resultado de las ventas y la relación con la marca son escasos. El propósito de este estudio es, por un lado, demostrar empíricamente el impacto del apego a la marca del vendedor (SBA) en el resultado de las ventas y, por otro lado, identificar los mediadores de esta relación en el comercio minorista. Diseño/metodología/enfoque - Se realizó una encuesta con una muestra de 206 vendedores de pequeños minoristas provenientes de diferentes sectores de un país emergente. El modelo estructural se analizó mediante ecuaciones estructurales basada en mínimos cuadrados (PLS-SEM) utilizando SmartPLS3.

Hallazgos - Los resultados mostraron que el SBA es esencial para impulsar el resultado de las ventas a través de dos caminos relevantes: uno siguiendo el SBA-satisfacción-rendimiento y la otra dirección siguiendo el SBA-compromiso-rendimiento. El modelo fue capaz de explicar el $63 \%$ del rendimiento.

Implicaciones prácticas - Con respecto a los pequeños minoristas, donde los propietarios, empleados y gerentes tienen niveles más altos de interacción que las grandes cadenas minoristas nacionales, los ejecutivos de marketing deben invertir en mejorar el apego a la marca y crear vínculos emocionales y cognitivos entre los vendedores y la marca. Deben desarrollar estrategias para promover la satisfacción laboral y el compromiso organizacional ya que determinan el rendimiento.

Originalidad/valor - A pesar de la relevancia de las pequeñas empresas para las economías de todo el mundo y la importancia de las relaciones de marca en los vendedores, no se ha desarrollado ningún estudio para demostrar los impactos de tales relaciones en el rendimiento de los vendedores en el comercio minorista. Además, aparte del papel central del compromiso organizacional en la investigación en ventas, este es el primer estudio que explora cómo media la relación entre el apego a la marca y el resultado de las ventas.

Palabras clave - Comercio minorista, Vendedor, Apego a la marca, Compromiso organizacional, Satisfacción laboral, resultado de ventas, Pequeñas empresas

Tipo de artículo - Trabajo de Investigación

\section{品牌关系重要吗？品牌依恋在零售业销售人员业绩中的作用}

摘要

目的 - 销售人员的业绩被认为是零售业成功的一个相关因素。然而, 很少有研究揭示销售业绩和品 牌关系之间的关系。本研究的目的是, 一方面, 实证证明销售人员品牌依恋 (SBA) 对销售业绩的影 响, 另一方面, 确定小型零售业中这种关系的中介因素。

方法。一我们对一个新兴国家不同行业的206家小型零售商进行了调查。使用SmartPLS3中的偏最小 二乘法-结构方程模型（PLS-SEM）对提议的模型进行了检验。

研究结果。- 结果表明, SBA通过两条相关路径与推动销售业绩有关一一条是跟随SBA-满意度-业绩, 一条是跟随SBA-承诺-业绩。该模型能够解释 $63 \%$ 的结果表现。

实际意义。- 关于小型零售商, 其业主、员工和经理的互动水平比大型的全国性零售连锁店要高, 营 销主管必须投资于提高对品牌的依恋, 在营销人员和品牌之间建立情感纽带和认知。他们必须制定战 略来促进工作满意度和组织承诺, 因为它们决定了绩效。

原创性。一尽管小企业对全世界的经济都有意义, 而且销售人员的品牌关系也很重要, 但还没有研究 表明这种关系对零售业销售人员业绩的影响。此外, 除了组织承诺在销售研究中的核心作用外, 就作 者所知, 这是第一个探讨如何调解品牌依恋和销售业绩之间关系的研究。

关键词 - 零售业, 销售人员, 品牌依恋, 组织承诺, 工作满意度, 销售业绩, 小企业

文章类型 - 研究型论文 


\section{Introduction}

In the past, a salesperson's role was purely to mediate customer contact with the company; however, in recent years, the role has evolved beyond that, and it has become necessary for salespeople to create value for consumers and the organization (Schwepker, 2019; Badrinarayanan et al., 2019). Given this change, the importance of the salesperson as well as interest in gaining more knowledge about the factors that affect sales performance has grown simultaneously (Bagozzi et al., 2016). Within the sales performance literature, Churchill et al. (1985) conducted a relevant meta-analysis of the sales performance research that categorized six antecedents (role perceptions, aptitude, skill level, motivation, personal characteristics and organizational/environmental variables). Verbeke et al. (2011) developed a comprehensive meta-analysis (1982-2008) that demonstrated that role ambiguity, cognitive aptitude, involvement, degree of adaptability and sales-related knowledge are the main influencers of salesperson performance. Recent studies confirm these relationships but emphasize specific dimensions such as self-efficacy (Peterson, 2020), coworkers, buyers and situational factors (Herjanto and Franklin, 2019) and ethical issues (Badrinarayanan et al., 2019). However, a factor that can affect performance that has been considered in the more recent literature is the relationship that salespersons can develop with a brand (Hughes et al., 2019; Udayana et al., 2019). As the literature accepts that consumers develop relationships with brands, it makes sense that salespeople could also behave similarly. At present, however, the research into the relationship between sellers and brands remains scarce and is usually related to the perspective of the employer or talent retention (Hughes et al., 2019; Michel et al., 2015). Some of these studies focus on the connection between sales performance and brand relationships such as Hughes and Ahearne (2010), Michel et al. (2015), Gammoh et al. (2018) and Hughes et al. (2019). However, despite the significant number of previous studies, the capacity of explanation of these models, in general, substantiates less than $50 \%$ of salesperson performance, suggesting the existence of other variables.

The literature on consumer-brand relationships indicates that brand attachment is a relevant predictor of strong and stable relationships between firms and consumers, forging favorable attitudes and behaviors. Brand attachment is defined as the strength of the cognitive and affective link between an individual and a brand (Park et al., 2010). In other words, it denotes a psychological state of mind in which a strong cognitive and affective bond connects a brand to an individual in such a way that the brand is an extension of the self (Park et al., 2007). Therefore, Allison et al. (2016, p. 3) proposed the relevance of brand attachment for the sales field, suggesting that "the effect of brand attachment is likely to be particularly important for salespeople because their jobs rely on continual engagement with the brand." Raut et al. (2019) consider salesperson brand attachment (SBA) to be the emotion-laden bond connecting a salesperson with a specific brand (Raut et al., 2019).

The importance of small businesses and retailers can be verified because of their impacts on the economy. In Brazil, according to the Institute of Geography and Statistics - IBGE (2020), $26 \%$ of formal workers are allocated in retailing, which is the largest employer in the country. There are approximately 17 million companies in Brazil, and 99\% are classified as small businesses, representing $30 \%$ of the GDP (SEBRAE - Serviço Brasileiro de Apoio às Micro e Pequenas Empresas, 2020). In addition to these facts, retailing is the largest employer of salespeople in most countries, and the importance of small businesses is not an exclusive phenomenon of the Brazilian economy (Kim and Takashima, 2019). In the USA, there are approximately 30.7 million small businesses, which represent $99.9 \%$ of the total of all organizations (SBA - US Small Business Administration, 2019). Small organizations create 1.5 million job openings per year and registered $64 \%$ of new job openings in the USA
Does brandrelationships matter? 
SJME

26,1

in 2019. They generate approximately $61.3 \%$ of added value and $71.9 \%$ of total employment, which are percentages similar to those observed in the European Union.

However, despite the relevance of small business performance for economies worldwide and the importance of brand relationships in the literature, only a few studies have sought to explore the impacts of salesperson brand relationships on sales performance (Gillespie and Noble, 2017; Gammoh et al., 2018). Additionally, no study has been developed regarding instore retailing, which represents approximately two-thirds of the GDP in most economies (Hughes et al., 2019; Kim and Takashima, 2019; Investopedia, 2020). Furthermore, in addition to the central role of organizational commitment in the sales literature (Verbeke et al., 2011; Jaramillo, 2005), no research has explored how it could mediate salesperson brand relationships with sales performance.

Accordingly, the following two research objectives frame the intended contribution of our study:

(1) to empirically demonstrate the impact of SBA on sales performance in small businesses; and

(2) to identify the mediators of this relationship within the segment of in-store retailing.

This study, thus, contributes to the previous research in the following ways. First, we extend salesperson-brand relationship studies to the small business/retailing segment. Second, we enhance our comprehension of the effects of SBA by showing how it affects relevant salesperson attitudes. Third, we demonstrate how these attitudes mediate the effects of brand attachment on salesperson performance through two significant paths. Finally, we develop managerial insights from our research as it explains a significant part of performance, allowing small retailers more efficiently manage sales teams.

The article is structured as follows. The introduction is presented in Section 1, and the conceptual background is set forth in Section 2. The development of the research hypotheses is provided in Section 3, and the methodology and results are described in Section 4. The discussion is provided in Section 5. Finally, Section 6 sets forth the final considerations, presented as managerial implications, research limitations and future research directions.

\section{Conceptual background}

\subsection{Role of the salesperson in the small retail sector}

Retail studies are recurrent in the literature for a variety of reasons (Cortinas et al., 2019) such as their representativeness in an economy, their ability to create jobs and their financial turnover. Moreover, research topics that consider online sales are now also being included. However, the focus of the retail research is usually from the perspective of Western and developed countries (Lenartowicz and Balasubramanian, 2009), with a gap in retail studies in emerging countries, as observed by Nanarpuzha and Noronha (2016) in their research of small retailers in India.

Small retailers are usually located in regions farther from larger urban centers and/or in areas with greater socioeconomic needs, acting as liaisons between consumers and brands to meet consumers' most urgent demands. Such small retailers often take the form of neighborhood stores (Barki and Parente, 2010) as they seek to settle near consumers to facilitate access, which is not always easy because of the difficulties in commuting for lower income populations. The retail store is the link that has the most contact with consumers and their needs and desires, especially those that serve low-income populations (Kim and Takashima, 2019). One of the most relevant characteristics of such stores, which is a testament to an understanding of low-income groups, is the importance of personal contact 
and the development of relationships (Badrinarayanan and Laverie, 2011). For this income category, it is crucial that when interacting with the customer, the retail store demonstrates genuine concern for the situation and the customer's needs (Barki and Parente, 2010).

Although progress has been made in this area, the research is not yet fully conclusive in its findings on the network of variables with regard to consumer buying behaviors, especially those related to small retail establishments (Nanarpuzha and Noronha, 2016).

Therefore, considering the context of emerging countries with consumers who have lower purchasing power, which correlates with a greater demand for attention from the salesperson, the salesperson's role becomes even more relevant. Studying how salespeople can improve their relationship with a brand is important to ascertain the impact it can have on their performance.

\subsection{Salesperson brand attachment}

The notion that consumers have strong attachment or strong brand connections is firmly rooted in the consumer research. Brand attachment has been defined as the strength of a brand's connection with consumers (Gillespie and Noble, 2017). When consumers feel a strong connection with a brand, their consumption of that brand then serves to enhance their identity and allows them to forge, develop and expand their social network (Fournier and Alvarez, 2012). Brand attachment has been termed "the ultimate customer destination-brand relationships" (Park et al, 2010, p. 2). Unsurprisingly, building brand attachment has stimulated a significant amount of research and attention in the field of consumer marketing.

Consistent with attachment theory, brand attachment is a broader construct that captures the individual's emotional and cognitive links with the target brand in addition to the extent to which brand attachment is associated with the target brand and the individual's mental awareness of that brand. Attachment can be driven by identity (i.e. the brand reflects the self) as well as by instrumentality (i.e. the brand is meaningful to the person vis-à-vis their personal goals and concerns) (Park et al., 2010). However, according to Tsai (2011), brand attachment is defined as a profound passion for a brand and is characterized by the determination to own the brand and the willingness to make sacrifices for it. While the existing marketing research has underscored the importance of consumer brand attachment as a resource (Fournier and Alvarez, 2012; Thomson et al., 2005), the idea that brand attachment can also serve as an important resource for salesperson management has not yet been considered in depth.

Particularly intriguing is the potential for brand uptake that serves as a resource to inspire greater sales effort among salespeople and to influence salesperson performance (Gammoh et al., 2018; Mallin et al., 2017). For Allison et al. (2016), the self-connection of brands and salespeople can serve as a resource that can simultaneously benefit salespeople at work and improve brand outcomes. Hughes and Ahearne (2010) acknowledge that the salesperson's identifying with the brand has an important bearing on sales. The general idea is that brand identification involves the role played by the salesperson in the game of attachment.

It has also been suggested by other authors that the effect of brand attachment is particularly important for salespeople because their jobs depend on an ongoing commitment to the brand. Salespeople's role also offers them the opportunity to foster positive brand impressions among business-to-business (b2b) customers and to build brand equity on behalf of the company. Salespeople are responsible for how customers and employees interact (Sirianni et al., 2013). Thus, salespeople become the most visible representation of an organization's successes and failures.

Allison et al. (2016) argue that brand attachment is a key resource for salespeople, who should decrease stress and increase engagement (among potential customers). The salesperson will naturally be more engaged and committed to selling a brand to which they feel more
Does brandrelationships matter? 
SJME

26,1

attached (Bagozzi et al., 2016). Nevertheless, these authors recognize that this relationship is complex and can be influenced by several factors, including organizational characteristics.

Based on the considerations presented in the literature, SBA is considered to boost salesperson attitudes and performance, contributing to firms' results. Allison et al. (2016) took advantage of the gap and performed the first study of brand attachment from the perspective of salespeople. This investigation, based on work demands and resource theory, argues that SBA is an exclusive psychological resource for salespeople and provides empirical evidence that SBA increases sales effort and, ultimately, job satisfaction. After this initial study (Allison et al., 2016), only a few studies on SBA were conducted. Table 1 presents the existing research and the associated findings.

In Table 1, we observe that the studies were conducted in large companies, and most of them concerned business-to-business (b2b) relationships. There is only one study that is business-to-customer (b2c) related; however, it deals with direct marketing, which is pertinent to "peer-to-peer" direct sales, with no physical store involved. No study includes commitment and performance in the model, as recommended in the representative sales literature (Verbeke et al., 2011; Jaramillo, 2005), and not one was executed on small retailing. In this sense, there is a gap related to understanding how salesperson-brand attachment operates to drive salesperson performance in small business retailers.

\subsection{Salesperson performance}

In recent years, salesperson performance has gained relevance in the literature (Badrinarayanan et al., 2019). One reason for the further research on this topic is the evolution of the sales function within organizations (Miao and Evans, 2007). Previously, the salesperson's role was purely to mediate the customer's contact with the company, whereas it is now necessary to create value for consumers and the organization. In addition, salespeople must increasingly address complex situations, from persuading buyers to building trust and meeting corporate goals (Herjanto and Franklin, 2019).

Important research in this area was done by Churchill et al. (1985) that included a metaanalysis on the drivers of sales performance, which were categorized as

- role perceptions;

- aptitude;

- skill level;

- motivation;

- personal characteristics; and

- organizational/environmental variables (Churchill et al., 1985).

Subsequently, Verbeke et al. (2011) conducted an investigation that shows role ambiguity, cognitive aptitude, work engagement, degree of adaptability and sales-related knowledge as the main influencers on salesperson performance. In this context, Schwepker (2019) considers function variables (Churchill et al., 1985), and particularly function ambiguity (Verbeke et al., 2011), to be among the most significant factors affecting salesperson performance.

Other research that has focused on salesperson performance includes that of Herjanto and Franklin (2019). In their research, the authors empirically synthesized the factors that affect the salesperson performance that was studied in the literature from 1986 to 2017. They found that personal, organizational, coworker, buyer and situational factors contribute to a salesperson's effectiveness. 


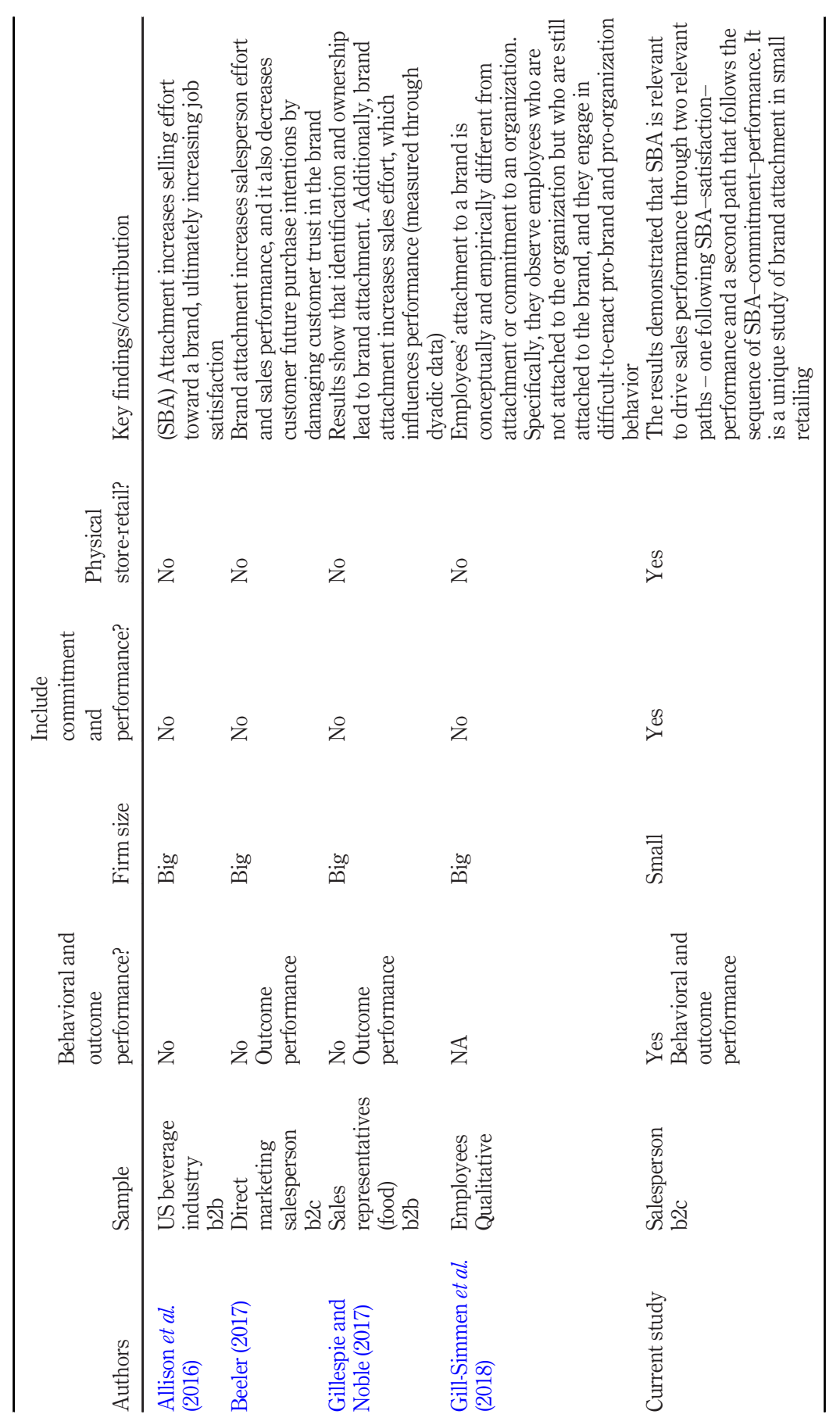

Does brandrelationships matter?

Table 1.

Studies about brand attachment and sales 
SJME

26,1

Therefore, according to the literature, several authors have reinforced the point that although there are some research efforts in the area, several gaps still need to be filled regarding salesperson performance, especially in small retail, where the breadth of this role is even more significant because of the multitude of the tasks performed (Badrinarayanan et al., 2019; Gammoh et al., 2018).

\section{4}

\section{Development of research hypotheses}

Veloutsou and Delgado-Ballester (2018) affirm that companies want strong brands, and to do so, they must develop a relationship between the brand and employee groups. As attempts in the literature to identify connections between brand relationships and sales are scarce, particularly with regard to their impacts on sales performance, the current study was undertaken. As explained above, the first study related to SBA was developed by Allison et al. (2016). However, their model did not explore the relationship of SBA with sales performance. Further studies have continued to develop theoretical implications and empirical evidence within the field; however, no study has considered brand commitment and brand attachment as the antecedents of performance, contradicting the suggestion of robust meta-analytic evidence such as that presented by Verbeke et al. (2011), Jaramillo (2005) or Michel et al. (2015).

Considering the above, this research proposes a comprehensive model to explain salesperson performance. It integrates the previous evidence that SBA affects brand selling effort and job satisfaction (Allison et al., 2016) with the proposal of Michel et al. (2015) who demonstrated that salesperson-brand relationships are an important antecedent of organizational commitment and motivation. Finally, the current research considers studies such as that of Miao and Evans (2007) demonstrating that job motivation can drive sales performance implemented by two different facets: behavioral performance (actions aligned with performance) and outcome performance (final sales results). In this sense, consistent with the literature, a nomological chain was proposed to build an integrated model to explain the effects and mediators of brand attachment on sales performance in small retailers. The model is presented in Figure 1.

The development of the hypotheses is described in the following sections.

Figure 1.

Conceptual model and research hypotheses

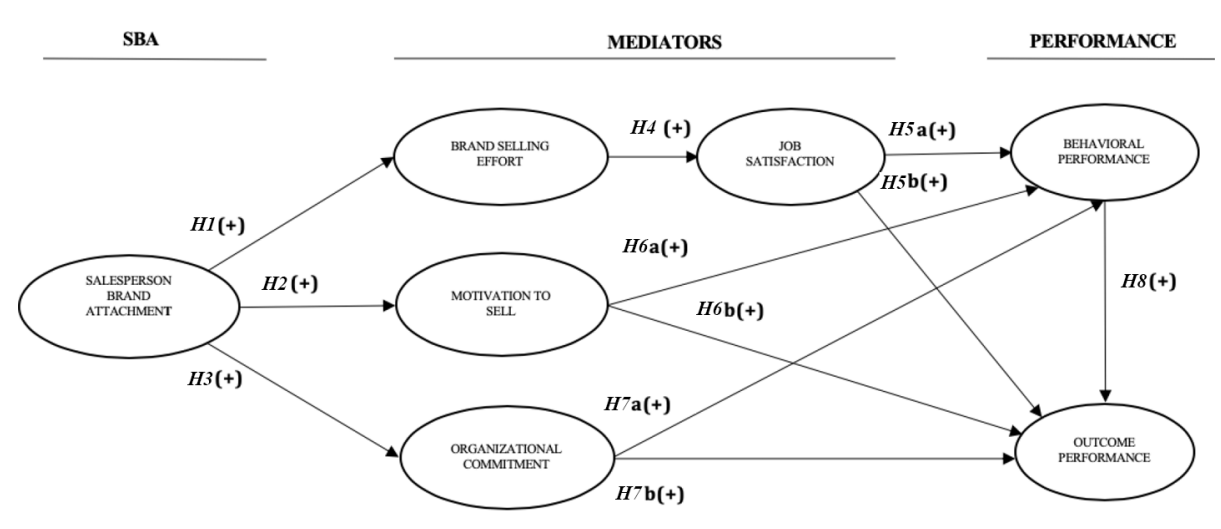

Source: Developed by the authors 


\subsection{Consequences of salesperson brand attachment}

Brand attachment has been broadly studied in the consumer-brand relationship literature, and it is accepted that it can boost consumers' commitment, loyalty and purchase intentions (Fetscherin, 2020). Therefore, a relevant question has intrigued researchers: should brand attachment be studied more extensively from the seller's perspective? (Gammoh et al., 2018; Gillespie and Noble, 2017). In conjunction with this issue, brand selling effort can be defined as the involvement of a salesperson in the sales process, in addition to the strength and energy spent doing the job, which may be related to the ability to exert more effort, be more persistent and be better able to handle the challenges of sales tasks (Kwak et al., 2019). Allison et al. (2016) define brand-selling effort as a determined sales attempt to achieve a goal, suggesting that the achievement of a goal leads employees to obtain a higher sense of accomplishment or job satisfaction. In a similar vein, Gammoh et al. (2018) argue that identification with the brand serves as a direct motivator to engage in selling and to adopt a more intense brand-selling effort. Fu et al. (2017, p. 260) argue that there is an "emotional tie" that connects salespeople to the brand they sell. Beeler (2017) found empirical evidence that brand attachment increases sales effort and consequently sales performance. This same evidence is presented in the research of Gillespie and Noble (2017), who found a positive relationship between brand attachment and selling effort. However, this empirical evidence was not obtained in small retailers. It, therefore, makes sense that brand attachment drives brand-selling effort in small retailing, which prompts the proposal of the following hypothesis:

\section{H1. Salesperson brand attachment has a positive impact on brand-selling effort.}

Motivation is a recurrent theme in sales performance literature (Bagozzi et al., 2016). Khusainova et al. (2018) argue that the amount of dedication that the salesperson expends to execute their activities relative to sales can be considered to be employee motivation. Michel et al. (2015) suggest that the relationships developed by employees with brands can trigger positive attitudes such as company evangelism, positive word-of-mouth and motivation. Along the same lines, Gommah et al. (2014) empirically demonstrated that more developed relationships between sellers and brands, represented by higher levels of brand identity and personality congruence, are important drivers of salesforce outcomes, affecting motivation and performance. Furthermore, according to attachment theory, an individual will present behaviors that are considered to be in increasing proximity to the attached object, corroborating the hypothesis that brand attachment leads to increased dedication and motivation. Fu et al. (2017) assert that emotional bonds connecting the seller with the brand allow the seller to be more stimulated to fulfill the tasks and challenges of sales work, suggesting an association between brand attachment and the motivation to sell. Considering the above, the following hypothesis was proposed:

\section{H2. Salesperson brand attachment has a positive impact on the motivation to sell.}

The seminal definition of organizational commitment proposed by Allen and Meyer (1990) suggests that this construct is related to the extent to which employees are linked to the company and believe in its values and vision. Employees who have an emotional attachment to a brand are expected to become more committed to the organization. In this sense, Eliyana and Ma'arif (2019) support the idea that organizational commitment relates to the intentions of a salesperson to stay in the firm as a group member, share values and deploy behaviors aligned with organizational aspirations and culture, suggesting a positive relationship of commitment to brand attitude. Sepulcri et al. (2020) assert that an employee's relationship
Does brandrelationships matter? 
SJME

26,1

with a brand impacts their organizational commitment because the more they are able to identify with a brand, the more involved they will become. In this sense, Sreejesh (2014) presents empirical evidence that brand attachment influences brand commitment. However, $\mathrm{Fu}$ et al. (2017) suggest that the seller's relationship with the brand creates a sense of belonging between the seller and the brand, generating more committed behavior. In this sense, Michel et al. (2015) prove that organizational commitment is influenced by a secondorder construct defined as the salesperson brand relationship. Thus, it is considered plausible that in small retailing, salespeople with a greater brand attachment will become more committed to the organization, which elicited the proposal of the following hypothesis:

H3. Salesperson brand attachment has a positive impact on organizational commitment.

The intensity, strength and energy exerted by an employee to perform their work is defined in the literature as an employee's work effort (Brown and Peterson, 1993). In the sales field, a salesperson's effort is related to the intensity that a salesperson applies to the recommendation and support of a specific brand as well as the inclination to sell one brand over another (Badrinarayanan and Laverie, 2011). This sales effort is not only associated with the number of hours dedicated to work but also with the intensity used to implement sales strategies (Kwak et al., 2019). Another relevant construct in the literature regarding the performance of salespeople is job satisfaction. Job satisfaction is referred to as a contributory factor in explaining salesperson outcomes and goal achievement (Rutherford et al., 2019). Eliyana and Ma'arif (2019) define job satisfaction as to how the employee feels about their job, their requirements, the results, the goals achieved and the organizational feedback received. Brown and Peterson (1994) explored the antecedents of sales performance in a sample of door-to-door salespeople (direct sales of durable products), and they observed a high impact of sales effort on satisfaction. Similarly, Allison et al. (2016) conducted a study with business-to-business salespeople of beverages and demonstrated a significant impact of selling effort on job satisfaction. These findings suggest that brand-selling effort and satisfaction can be associated with different sales contexts, including small retailing, leading to the proposition of the following hypothesis:

H4. Brand-selling effort has a positive impact on job satisfaction.

\subsection{Antecedents of salesperson performance}

According to Eliyana and Ma'arif (2019), there is a propensity for satisfied employees to perform better at work because employees with a high level of satisfaction tend to perform their jobs with more quality, which impacts the bottom line. Similarly, dissatisfied employees tend to perform less successfully (Brown and Peterson, 1993). To study this phenomenon, this research adopted the two-dimensional job performance perspective, which consists of behavioral and outcome performance (Miao and Evans, 2007; Baldauf and Cravens, 2002). The first perspective refers to the activities performed by salespeople during the sales process. The second refers to the quantitative results of salespeople's efforts (Badrinarayanan et al., 2019; Schwepker, 2019; Miao and Evans, 2007). In this sense, in an attempt to verify the relationship between job satisfaction and performance, some studies, such as Rutherford et al. (2019) and Kwak et al. (2019), which suggest a positive association, are observed in the literature. However, Judge et al. (2001) observed a negative correlation between these constructs. It is, therefore, believed that job satisfaction can influence both the 
behavioral performance and the outcome performance of small retailers; concerning this understanding, the following hypothesis was proposed:

H5. Job satisfaction has a positive impact on (a) behavioral performance and (b) outcome performance.
Does brandrelationships matter?

According to Schrock et al. (2016), companies invest in motivation and training programs to provide their workers with a higher performance environment. In this sense, Giacobbe $e$ t al. (2006) accomplished a business-to-business study and found that motivation presented a significant indirect effect on salespeople's performance. Similarly, based on a sample of US sales managers, Miao and Evans (2007) observed that the motivation to sell offered an indirect effect on both perspectives of salesperson performance: behavioral and outcome. However, the results of the meta-analysis elaborated by Verbeke et al. (2011), which considered 268 previous studies, observed that the motivation to sell presented a consistent but mild effect on sales performance. These authors also demonstrated differences regarding this effect between firms that sell products and services; however, they did not present results and comparisons of accomplishing variables such as firm size or economic activity. Meanwhile, Michael et al. (2015) propose that further research is required to explore the phenomenon in specific contexts, such as retailing, because of the particularities of this organization profile. In this sense, we propose that the motivation to sell impacts salesperson performance in small retailing, suggesting the following hypothesis:

H6. The motivation to sell has a positive impact on (a) behavioral performance and (b) outcome performance.

Fu et al. (2017) argue that organizational commitment can be associated with employee involvement with a company or how much they believe in the organization's values and vision, consequently affecting employee performance. That is, when an employee is more engaged, they will do their best, sacrifice themselves and have a high level of loyalty to the organization, which will raise their commitment to perform in a superior way (Verbeke et al., 2011; Schrock et al., 2016). Jaramillo et al. (2005) conducted a meta-analysis of the relationship between organizational commitment and salesperson job performance, encompassing 25 years of research. They observed an impact of $6 \%$, considering that the analysis included organizations of different sizes and from different regions. However, they could not compare how this relationship occurs according to different firm sizes or with regard to the type of business (i.e. manufacturers versus retailers) because of sample characteristics. Moreover, some researchers, such Rafiei et al. (2014), have suggested that if employees have a low level of commitment, they will not tend to show a high degree of responsibility and will care less about the performance of their duties. The most recent research, such as that of Eliyana and Ma'arif (2019), also corroborates these arguments. Therefore, we suggest that organizational commitment affects salesperson performance in small retailing, mediating the effects of brand attachment:

H7. Organizational commitment has a positive impact on (a) behavioral performance and (b) outcome performance.

\subsection{Relationship between behavioral performance and outcome performance}

Rafiei et al. (2014) consider that the success of an organization depends on the performance of its employees. This performance can be considered according to the results achieved, the skill set and the actions performed during the execution of tasks, and the objectives 
proposed by the organization (Kwak et al., 2019). In the literature, behavioral performance can be considered to be teamwork, technical knowledge, planning and sales support, and outcome performance is considered to be the contribution of the salesperson's results to organizational objectives (Schwepker, 2019). According to Baldauf and Cravens (2002, p. 1370), "higher behavior performance should lead to higher outcome performance. Both conceptual supporting logic and empirical evidence point to a positive relationship between behavior and outcome performance." Empirical findings in the sales management literature provide strong support for this association, such as the research by Theodosiou and Katsikea (2007), which they applied to export sales managers and found a positive effect of behavioral performance on outcome performance. Miao and Evans (2007) found an impact of 0.435 of behavioral performance on outcome performance with a sample of salespeople from 97 companies. This result conforms with those found by Jaworski and Kohli (1991). Thus, it makes sense that in small retailing, behavioral performance would boost outcome performance. Hence, the following hypothesis was proposed:

H8. Behavioral performance has a positive impact on outcome performance.

\section{Methodology}

The survey method was chosen to develop this study. The questionnaire data were collected in May 2017, with a sample of 206 salespeople of different brands in the six administrative regions of Belo Horizonte, which is the capital of the second most populous Brazilian state. The sample was distributed among women and men, as well as among high- and lowperforming salespeople, during their working hours. The respondents were retail salespeople who deal directly with consumers. A filter question was present at the beginning of the questionnaire to check the position of the respondent and to confirm their profile. The objective of this quota sampling methodology was to obtain a representative sample that was proportional to the stratum of small trades in the city. In this sense, the city was divided into nine sectors. The sample was distributed proportionally to the area of each sector, and data were collected in each sector with the agreement of the respondents. Quota sampling is a method of nonprobability sampling whereby the samples are selected proportionate to the distribution of a variable in the population and in which researchers look for a specific characteristic in their respondents (Rukmana, 2014).

The data were collected through face-to-face interviews. The scales used came from previous studies and included seven-point Likert-type scales: Brand attachment (nine items) (MacInnis and Folkes, 2010), Organizational commitment (three items) (Allen and Meyer, 1990), Brand-selling effort (three items) (Sujan et al., 1994), Motivation to sell (four items) (Spiro and Weitz (1990), Job satisfaction (three items) (Arnold et al., 2009), Behavioral performance (four items) (Behrman and Perreault, 1982) and Outcome performance (four items) (Behrman and Perreault, 1982). To ensure the content validity of the scales and to confirm face validity, a panel of six experts in sales was used. A pretest was accomplished with 20 salespeople to validate the questionnaire. The scales and measurement properties are presented in the Appendix.

\section{Results and findings}

\subsection{Sample profile}

According to the sample, $70 \%$ of the interviewed salespeople are women working in fashion stores, mostly single (52\%). Regarding the sample profile of the companies, $77 \%$ are stores located on streets or in malls. A total of $93 \%$ of them work with the sale of physical products 
(not services). More than $60 \%$ of these retailers sell fashion and beauty products. A total of $64 \%$ of the interviewed establishments have an average price of products sold of US\$60.00.

\subsection{Exploratory analysis and assumptions}

When evaluating the missing data, that is, incomplete data in the questionnaires, a small amount ( $0.76 \%$ of the base) was observed, and no variable presented more than $5 \%$ missing data. No case had a significant number of missing data (greater than $10 \%$ ). Thus, for the scales, the preference was to conduct the data replacement by the simple linear regression method (Tabachnick and Fidell, 2007). To evaluate univariate outliers, two classification criteria were applied outside the limits of 3.00 deviations from the average. To identify cases with nonstandard combinations of values, referred to as multivariate outliers, the Mahalanobis distance (D2) was used. Four multivariate outliers were detected. Thus, univariate and multivariate cases were maintained because, on a scale of $0-10$, it is believed that their effect on the estimates would be minimal compared to the model test (Hair et al., 2006).

\subsection{Validity and assessment reliability}

The quality of the assessment was then verified by evaluating the dimensionality of the measurements. Exploratory factor analysis with main component extraction was also applied, retaining factors with higher eigenvalues (Gerbing and Anderson, 1988). Indicators with low commonalities (below 0.40) were excluded. Regarding construct validity and reliability, and to test the hypothetical model, partial least squares (PLS) estimation was adopted as PLS path modeling is considered to be a valid tool for structural equation modeling (Haenlein and Kaplan, 2004; Rigdon, 2016). According to Nitzl et al. (2016), PLS emphasizes its capacity to model both composites and factors and its estimate orientation. Additionally to these motivations, PLS is a useful tool for testing hypotheses mainly in complex path models in an explorative approach.

To verify the reliability and validity of the scales, a series of procedures were performed. In assessing convergent validity, the factor loadings of the constructs were found to be significant. All items had acceptable loadings in each scale $(>0.70)$ except the first item of brand-selling effort that was excluded (see the Appendix); we observe that more than $50 \%$ of the variance in a single indicator can be explained by the corresponding latent variable. The composite reliabilities of the adopted scales are above the recommended 0.70 threshold (the correlation between the latent variable and construct scores) defined by Dijkstra and Henseler (2015). The average variance extracted (AVE) for all scales exceeded 0.5, which indicated good convergent validity (Bagozzi and Yi, 1988). The reliability indexes are described in the Appendix.

To verify discriminant validity, the traditional method of discriminant validity analysis suggested by Fornell and Larcker (1981) was used. It is observed that the models denote a good quality of assessment and that all constructs reached discriminant validity. The authors also considered the HTMT discriminant validity test (Henseler et al., 2016). These results are presented in Table 2.

\subsection{Nomological validity and hypothetical model testing}

In this section, the structural model test of the study is presented, which was done by applying the structural equation modeling technique, given its potential to test models for measuring interrelationships between constructs in a single approach, in addition to considering the impact of assessment errors on estimates (Fornell and Larcker, 1981; Podsakoff and Organ, 1986).
Does brandrelationships matter? 


\begin{tabular}{|c|c|c|c|c|c|c|c|c|c|c|}
\hline \multirow{2}{*}{$\begin{array}{l}\text { SJME } \\
26,1\end{array}$} & \multirow[b]{2}{*}{ Constructs } & \multirow{2}{*}{$\begin{array}{l}\text { Composite } \\
\text { reliabilities }^{\mathrm{a}}\end{array}$} & \multirow{2}{*}{$\begin{array}{l}\text { Average variance } \\
\text { extracted }^{\mathrm{b}}\end{array}$} & \multicolumn{7}{|c|}{ Fornell-Larcker ${ }^{\mathrm{c}} / \mathrm{HTMT}^{\mathrm{c}, \mathrm{d}}$} \\
\hline & & & & BEPE & BRAT & BRSE & JOSA & MOSE & ORCO & OUPE \\
\hline \multirow{7}{*}{130} & BEPE & 0.92 & 0.75 & 0.86 & 0.52 & 0.49 & 0.54 & 0.53 & 0.75 & 0.80 \\
\hline & BRAT & 0.94 & 0.67 & 0.47 & 0.81 & 0.45 & 0.79 & 0.74 & 0.88 & 0.69 \\
\hline & BRSE & 0.84 & 0.73 & 0.34 & 0.35 & 0.85 & 0.56 & 0.48 & 0.60 & 0.55 \\
\hline & JOSA & 0.93 & 0.72 & 0.49 & 0.73 & 0.44 & 0.85 & 0.71 & 0.89 & 0.76 \\
\hline & MOSE & 0.84 & 0.57 & 0.44 & 0.63 & 0.32 & 0.60 & 0.75 & 0.81 & 0.64 \\
\hline & ORCO & 0.82 & 0.60 & 0.58 & 0.70 & 0.37 & 0.77 & 0.66 & 0.77 & 0.78 \\
\hline & OUPE & 0.89 & 0.68 & 0.70 & 0.61 & 0.41 & 0.67 & 0.51 & 0.58 & 0.82 \\
\hline
\end{tabular}

Notes: Values on the diagonal in italics are the square root of the average variance extracted (AVE) of each factor; values below the diagonal are correlations between factors and values above the diagonal are the HTMT ratios; ${ }^{a}$ Reliability; ${ }^{\mathrm{b}}$ convergent validity; discriminant validity; ${ }^{\mathrm{C}}$ Fornell-Larcker; ${ }^{\mathrm{C}}$ Heterotraitmonotrait: criteria confidence interval does not include 1; $\mathrm{HTMT}_{90}$ - Henseler et al. (2015); BEPE =

Table 2 . Behavioral performance; BRAT = Brand attachment; BRSE = Brand-selling effort; JOSA = Job satisfaction; Measurement model MOSE = Motivation to sell; ORCO = Organizational commitment. OUPE = Outcome performance

A frequent question in studies that adopt the quantitative approach involves sample size. Therefore, the criteria suggested by Hair et al. $(2017$, p.28) to calculate the sample size, for a statistical power of $80 \%$, were analyzed. Accordingly, the recommended minimum sample is 158 respondents (sig. level $=1 \%$; min. $R^{2}=0.1$ and $\max$ ind. $=4$ ). A post hoc verification of the adequacy of the sample size was evaluated through the calculation of the statistical power using the software $\mathrm{G}^{*}$ Power (Prajapati et al., 2010). We followed the procedures recommended by Ringle et al. (2015). The sample presented a statistical power of $96 \%$, which is higher than the $80 \%$ recommended threshold (Cohen, 1992; Hair et al., 2017). As an indicator of the overall predictive power of the model, the goodness of fit (GoF) measure was calculated, which indicated that $43.25 \%$ of the overall data variability is explained by the proposed predictive model. The hypotheses tested, the path coefficients, standard error, $t$ tests, significance, the size of the effects of the paths and results of the hypothesis tests are presented in Table 3.

In Figure 2, we present an analysis of the model's paths.

Table 3.

Result of the proposed model hypotheses

\begin{tabular}{|c|c|c|c|c|c|c|}
\hline$H$ & Relations & Path coeff. & $\mathrm{SD}$ & $t$ & $f^{2}$ Effect size & Result \\
\hline$H 1$ & Brand attachment $\rightarrow$ Brand-selling effort & 0.354 & 0.08 & 4.340 & 0.14 Small & Supp \\
\hline H2 & Brand attac & 0.636 & 0.051 & 12.30 & 0.68 Large & Supp \\
\hline$H 3$ & Brand attachment $\rightarrow$ Organizational commitment & 0.708 & 0.041 & 15.721 & 1.00 Large & Supp \\
\hline$H 4$ & ing effort $\rightarrow$ Job satisfaction & 0.442 & 0.07 & 6.10 & 0.24 Medium & Supp \\
\hline H5a & al performance & 0.094 & 0.10 & 0.910 & 0.00 None & Rej \\
\hline & Job sa & 0.463 & 0.09 & 4.990 & 0.23 Medium & Supp \\
\hline & Motiv & 0.092 & 0.11 & 0.810 & 0.00 None & Rej. \\
\hline$H 6 b$ & Motiva & 0.099 & 0.07 & 1.360 & 0.01 None & Rej. \\
\hline$H 7 a$ & Organ & 0.450 & 0.11 & 3.750 & 0.10 Small & Supp \\
\hline$H 7 b$ & Organizational commitment $\rightarrow$ Outcome perfor & -0.13 & 0.08 & 1.540 & 0.01 None & \\
\hline H8 & Behavioral performance $\rightarrow$ Outcome performance & 0.504 & 0.08 & 6.050 & 0.45 Large & Supp \\
\hline
\end{tabular}

Source: Research data. Model fit: SRMR $=0.0839 ; \quad$ d_ULS $=3.7195 ; \mathrm{dG}=1.6421 ; \quad \chi^{2}=1,815.9488$; $\mathrm{NFI}=0.6708$ 


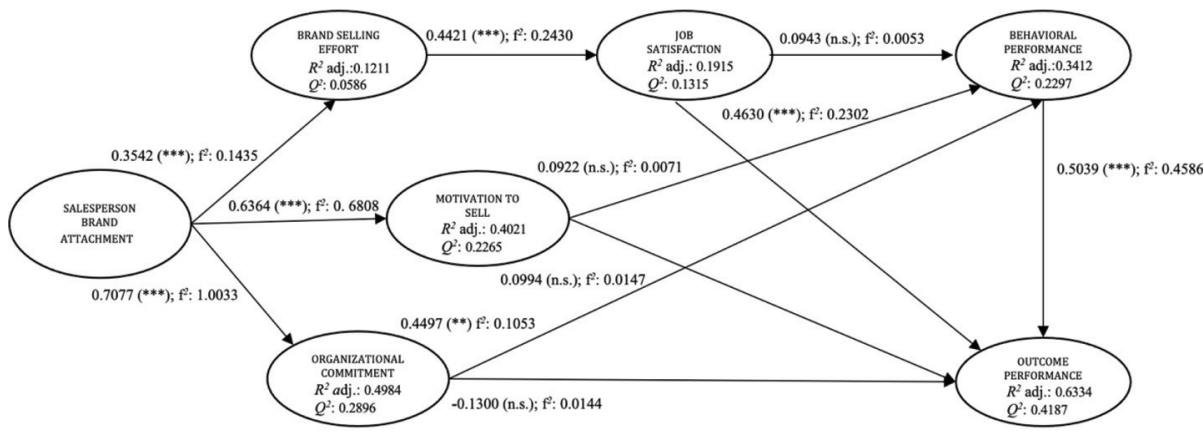

Does brandrelationships matter?

Notes: ${ }^{* * *} \mathrm{p}<0.001 ; * * \mathrm{p}<0.01 ;{ }^{*} \mathrm{p}<0.05$

Figure 2.

Structural model

The hypothetical model was able to explain $63 \%$ of outcome performance and $34 \%$ of behavioral performance. According to the results, brand attachment presented significant effects on all of its consequents: brand-selling effort ( $\beta=0.354, p<0.01, H 1$ supported); motivation to sell ( $\beta=$ $0.634, p<0.01, H 2$ supported); and organizational commitment $(\beta=0.707, p<0.01, H 3$ supported). However, brand-selling effort drives job satisfaction $(\beta=0.442, p<0.01$, $H 4$ supported), which subsequently impacts outcome performance ( $\beta=0.463, p<0.01, H 5 b$ supported) but does not influence behavior performance ( $\beta=0.094, p>0.05$, H5a rejected). In this sense, the results suggest that the first significant path to sales performance is brand attachment $\rightarrow$ effort $\rightarrow$ satisfaction $\rightarrow$ outcome performance. Conversely, in addition to brand attachment significantly impacting motivation to sell, it did not impact behavioral performance ( $\beta=0.092, p>0.05$, H6a rejected) or outcome performance ( $\beta=0.099, p>0.05, H 6 b$ rejected). However, a second path to performance was revealed through organizational commitment. The results demonstrate that organizational commitment plays a relevant role in mediating the effects of brand attachment and sales performance. Brand attachment presented a significant effect on organizational commitment, suggesting that in small retailing, a business in which owners, managers and salespeople work physically nearer in day-to-day operations, it is relevant to drive attachment to obtain commitment and performance. According to the results, organizational commitment drives behavioral performance $(\beta=0.450, p<0.01, H 7 a$ supported); however, it does not present a direct effect on outcome performance $(\beta=-0.130$, $p>0.05, H 7 b$ rejected). In addition, behavioral performance impacts outcome performance ( $\beta$ $=0.504, p<0.01, H 8$ supported), suggesting a second path to salesperson performance: brand attachment $\rightarrow$ org. commitment $\rightarrow$ behavioral performance $\rightarrow$ outcome performance.

In addition to the capacity of explanation of the relevant constructs of the model (i.e. outcome performance explained $63.34 \%$ of its variation), as well as the significant paths, the overall adjustments of the model suggest improvements. The standardized root mean square residual (SRMR) original value was near the threshold of 0.08 in the saturated model suggested by Hu and Bentler (1999) and of 0.10 proposed by Ringle et al. (2015), and it was higher in the estimated model (there is a discussion about which model should be used). The exact model fit tests the statistical inference of the discrepancy between the observed covariance matrix and the covariance matrix inferred by the composite factor model (SmartPLS ${ }^{\mathrm{a}}$, 2021). Dijkstra and Henseler (2015) define d_ULS as the squared Euclidean distance and d_G as the geodesic distance, and these indicators represent two distinct approaches to evaluate this discrepancy. The bootstrap routine provides the confidence intervals of these discrepancy values. After Bollen-Stine bootstrapping, d_ULS and d_G 
SJME

26,1

132

values were not included in the confidence interval, suggesting that the model does not fit perfectly within the data collected. The fit obtained could be related to issues such as the existence of nonsignificant hypotheses within the reality of retailing as former studies that supported the hypothetical model have been focused on $\mathrm{b} 2 \mathrm{~b}$ markets.

Therefore, to explore the phenomenon more deeply and to explain salesperson performance in small businesses, a rival model was proposed and tested. For this, a series of theoretical elements were added, and some procedures were performed. First, the nonsignificant paths were removed as they do not contribute to the explanation of performance: organizational commitment $\rightarrow$ outcome performance and job satisfaction $\rightarrow$ behavioral performance. Second, in addition to the fact that motivation to sell receives the impact of brand attachment, it does not present a significant impact on performance and is excluded. In the sequence, it was found that brandselling effort presented an $R^{2}$ of $12.5 \%$. This construct acts as a mediator between brand attachment and performance, marginally contributing to the nomological chain. These facts can be confirmed by analyzing the small indirect effects of brand-selling effort on performance $(0.04$ and 0.02). Consequentially, this construct was excluded.

Additionally, we directed our attention to the literature to understand the phenomenon, according to small business retailers, seeking signs of theoretical evidence according to the results of the original model. In this sense, it was observed, according to Raut et al. (2019), that brand attachment will induce the employee to nurture a greater desire to invest more time, talent and effort in activities that can sustain their relationship with the brand. Previous studies such as Dennis et al. (2016) argue that the stronger the link with the brand, the greater the salesperson' satisfaction, a fact that was confirmed by Allison et al. (2016). In this sense, we propose that SBA would have a positive impact on job satisfaction. However, job satisfaction is related to employees' emotions and attitudes toward their jobs, which in turn could present empirical evidence that job satisfaction will impact commitment in small businesses. Siong et al. (2006) indicate that the dissatisfaction of employees also generates a reduction in commitment to organizations. We, therefore, propose that job satisfaction will present a positive impact on organizational commitment. A rival model is presented in Figure 3.

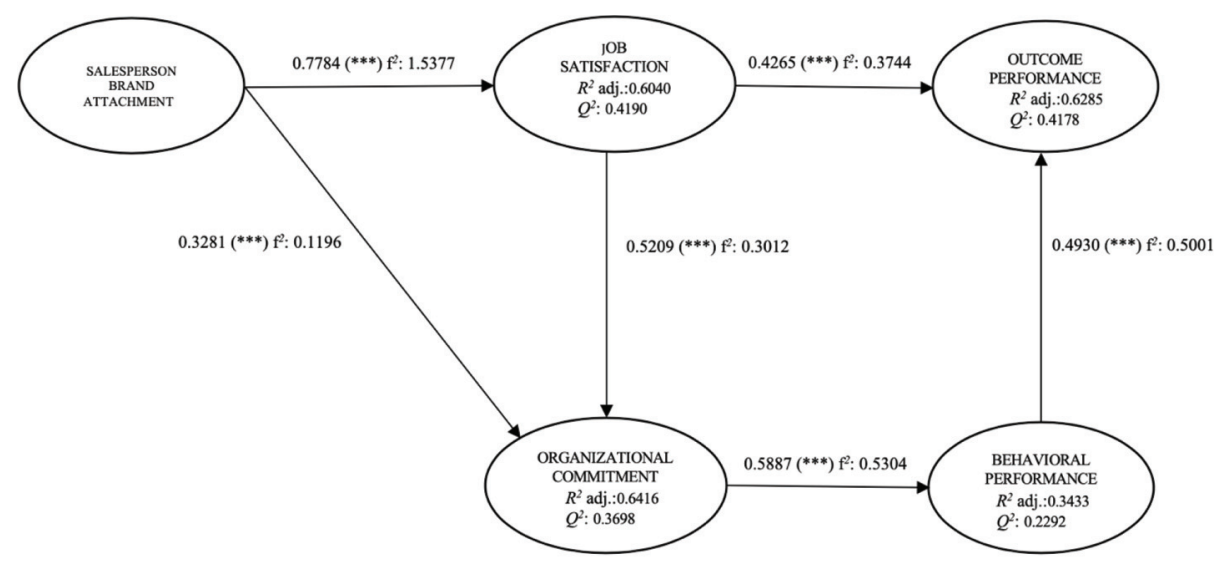

Figure 3.

Alternative model. Brand attachment in retail and salesperson performance

Notes: ${ }^{* *} \mathrm{p}<0.001 ;{ }^{* *} \mathrm{p}<0.01 ;{ }^{*} \mathrm{p}<0.05$ 
The results of the path analysis are described in Table 4. As we observe, all the hypotheses were supported, and all the effect sizes are significant.

The capacity of the model to explain the constructs was good (most $R^{2}$ greater than $60 \%)$. According to Hair et al. (2017), $Q^{2}$ values $>0.35$ indicate large levels of predictive relevance, $>0.15$ medium and $>0.02$ a small level. Most constructs present large levels, except for behavioral performance, such as $Q^{2} 0.22$ (medium). For approximate fit indexes such as SRMR and normed fit index (NFI), we analyzed the outcome model estimation and each criterion's values with a certain threshold (e.g. SRMR $<0.10$ and NFI $>0.90$ ). The original SRMR value is lower than the threshold of 0.08 suggested by Hu and Bentler (1999). The confidence interval of SRMR included the original value of SRMR for the estimated model $(99 \%)$, indicating adequate fit. The NFI value obtained was 0.8014 , which is near the suggested threshold. As there is more than one way to quantify the discrepancy between two matrices, for instance, the geodesic discrepancy (dG) or the unweighted least squares discrepancy (d_ULS), a transparent reporting practice should always include several tests (Henseler et al., 2016). Additionally, different tests may produce different results; therefore, different tests were carried out, and we observed that the model fits well for d_ULS (est. = 1.9057; limit. 99\% = 2.2883). The model therefore presents adequate results (Henseler et al., 2016), considering the analysis of the structural model $\left(R^{2} ; \mathrm{Q}^{2}\right.$; coefficients, significance and effect size); the overall model fit (SRMR and d_ULS $<99 \%$ bootstrap quantile); and measurement model (SRMR $<0.08$; Cronbach's $\alpha>0.7$; AVE $>0.5$; HTMT $<0.90$ sig.; Fornell-Larcker criterion).

According to the results of the rival model, we observed that the model was able to explain $63 \%$ of outcome performance and $35 \%$ of behavioral performance. This capacity of explanation of $63 \%$ with just four antecedents suggests that a small number of variables can contribute to forging outcome performance in small retailers. SBA revealed a strong impact on job satisfaction $(\beta=0.778)$ and organizational commitment ( $\beta=0.328$ ), all of which were significant at the 0.01 level. Meanwhile, we observed that SBA explained $60.6 \%$ of job satisfaction, and both explained approximately $64.5 \%$ of organizational commitment.

We also observed interesting results regarding the determinants of performance. We verified that behavioral performance, which is related to activities performed by salespeople during the sales process, was uniquely impacted by organizational commitment $(\beta=0.589)$. It was also observed that behavioral performance

\begin{tabular}{lcccl}
\hline Constructs & Path coefficient & $p$-Value & $f^{2}$ & Effect size \\
\hline BEPE $\rightarrow$ OUPE & 0.4930 & 0.0000 & 0.5001 & Large \\
BRAT $\rightarrow$ ORCO & 0.3281 & 0.0001 & 0.1196 & Small \\
BRAT $\rightarrow$ JOSA & 0.7784 & 0.0000 & 1.5377 & Large \\
JOSA $\rightarrow$ OUPE & 0.4265 & 0.0000 & 0.3744 & Large \\
JOSA $\rightarrow$ ORCO & 0.5209 & 0.0000 & 0.3012 & Medium \\
ORCO $\rightarrow$ BEPE & 0.5887 & 0.0000 & 0.5304 & Large
\end{tabular}

Source: Research data. Effect size: $f^{2} \geq 0.02, f^{2} \geq 0.15$ and $f^{2} \geq 0.35$ represent small, medium and large effect sizes, respectively. Model fit: SRMR $=0.0720$; d_ULS $=1.6836$; d_G $=0.8035$; Chi-square $=901.6369$; $\mathrm{NFI}=0.8009$
Does brandrelationships matter?

133

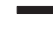


SJME

26,1

demonstrated a relevant impact on the objective results of sales-outcome performance $(\beta=0.493)$.

Despite the literature suggesting that the motivation to sell is a relevant driver of sales performance, the inclusion of brand attachment in the original model created only two different paths to performance (through commitment and job satisfaction), transforming motivation to sell into a nonsignificant antecedent of performance. These results suggest that brand attachment can partially capture the variances of "motivation to sell" in small retailers, a fact that enhances its relevance to the role in this industry. However, job satisfaction presented a significant direct impact on outcome performance, with $\beta=0.426$ and a direct effect on organizational commitment $(\beta=0.521)$.

To obtain more detail about the effects of brand attachment on salesperson performance, and explore the results, a mediation analysis was performed. The analytical approach described by Nitzl et al. (2016) was adopted, which is implemented at SmartPLS3 (SmartPLS $\left.{ }^{\mathrm{b}}, 2021\right)$. First, a bootstrapping procedure was accomplished with resampling of 5,000, with a 95\% bias-corrected bootstrap confidence interval. Following the recommendations of Cepeda et al. (2017), mediating effect tests were estimated, providing data about direct effects, indirect effects, total effects, CI-bias and type of mediation. The results are presented in Table 5 .

The analysis of the indirect and total effects reveals that brand attachment presents a total impact of 0.5449 on outcome performance and of 0.4319 on behavioral performance, which demonstrates its importance in terms of explaining salesperson performance in small retailing. The results also reveal that SBA presents an indirect effect on organizational commitment (0.4055), with a relevant total effect of 0.7336 . Finally, we observe job satisfaction has indirect effects on behavioral and outcome performance, mediated by organizational commitment.

\section{Discussion and implications}

This research aimed to propose and test a model that explored the impact of SBA on salesperson performance in small retailing. The comprehensive model presented SBA as a driver of salesperson performance evaluated through two perspectives. The original and rival models presented were able to demonstrate a significant capacity to explain salesperson performance.

\subsection{Theoretical implications}

According to the results, brand attachment boosts sales performance through two different paths. The first path is mediated by job satisfaction, a construct with a more transitory and variable nature. The second path is mediated by organizational commitment, which is a more stable predictor of behavior. Therefore, the way in which these paths interact should reveal routes to growth in sales performance. Regarding the first path, we observe that brand attachment impacts job satisfaction, which directly influences outcome performance. This means that an attached salesperson would be more satisfied, and during the time this level of satisfaction is maintained, their sales performance will increase.

However, the second path operates with organizational commitment as a mediator. Organizational commitment is related to long-term promises and conative intentions to continue with a relationship (Eliyana and Ma'arif, 2019). It represents an accumulated moral obligation to remain with the organization reflecting the employee's relationship with the organization. Therefore, when an employee is more committed, they will do their best and have a higher level of loyalty to the organization and perform in a superior way (Meyer and 


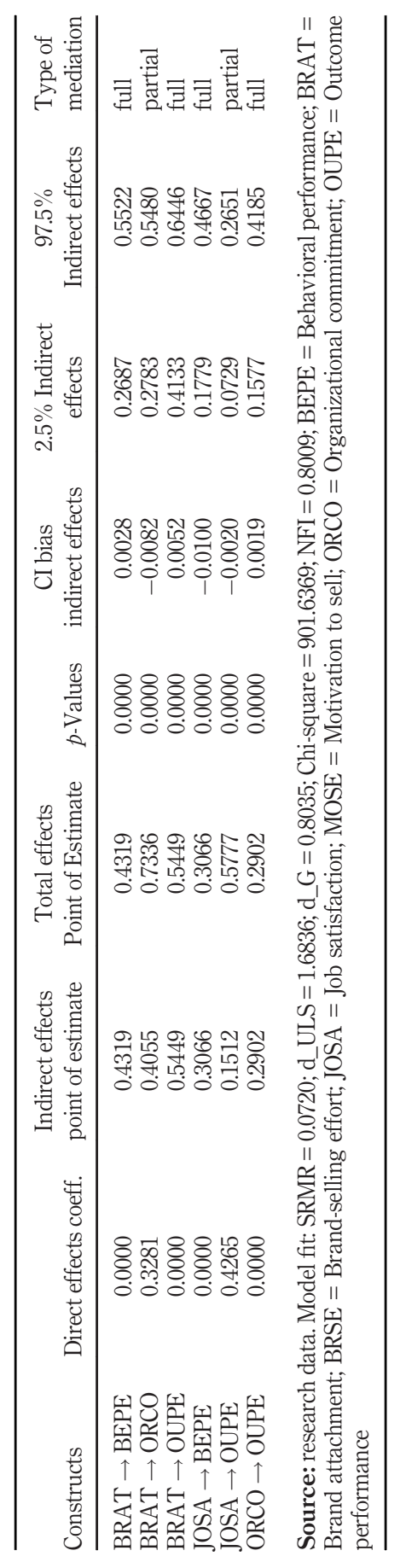

Does brandrelationships matter? bias corrected) 
Allen, 1991). Conversely, the results confirm this theoretical proposition, demonstrating that organizational commitment drives behaviors and habits (behavioral performance) in small retailers as a longstanding dimension of salesperson performance. However, despite job satisfaction being an immediate driver of performance, the results suggest that it will be "stored" as organizational commitment to boost future behavioral performance. Therefore, we conclude that salesperson performance is a consequence of two interrelated paths (satisfaction and commitment) and that SBA has a relevant capacity to boost the performance of salespeople in small retailers.

Finally, we conclude that this research extends the study of salesperson performance by developing and testing a model that considers brand attachment as a relevant driver of salesperson performance. The results prove this significant influence and demonstrate the existence of two significant paths. In this sense, this is a unique study that describes the relevance of brand attachment in small retailing, demonstrating its impacts on salesperson performance and presenting relevant mediators as organizational commitment, contributing theoretical and managerial implications.

\subsection{Practical implications}

From a managerial perspective, current managers face strong competition in an increasingly broad and complex scenario. In this context, brands play an important role when faced with the growth of virtual interactions and the growth of e-commerce. Sepulcri et al. (2020) theorize that brands become the center around which an organization's processes are created through interactions, and they are closely linked to business development and financial performance. Specifically, according to Cortiñas et al. (2019), the retail world is changing, and retailers must have a more comprehensive view of how they should seek different strategies to add more value to the business and generate better performance. Given this context, the current research offers interesting implications. The results obtained signify that companies should dedicate their efforts directly to points that will induce improved performance, especially in small retail, considering its importance in terms of its contributions to employment and for the national economy of a wide range of countries.

This research demonstrated how brand attachment is relevant to boosting sales performance in small retailers. Brand attachment presented two paths to drive performance: one through job satisfaction and the other through organizational commitment. As attachment can be driven by a consumer's identity congruence (i.e. how the brand reflects the self), as well as by instrumentality (i.e. the brand is meaningful to the person concerning their personal goals and concerns), managers should focus on nurturing these elements considering that salespeople are representatives of the brand. They should also invest in enhancing individual salespeople's emotional and cognitive links with the brand as these links comprise the core of brand attachment (Park et al., 2010). This is because, in small businesses, employees, managers and owners face deeper and more frequent personal interactions than in larger firms. In this sense, brand attachment would assume a crucial role in driving salesperson performance and job satisfaction in small stores. However, for larger stores and chains, managers will face more challenges in forging brand attachment as the owner is present less often and will be represented by employees, managers and internal communication activities. Because of the COVID-19 pandemic, a considerable volume of sales has migrated from larger to small local stores and from brick-and-mortar stores to ecommerce. Therefore, managers face a multifaceted phenomenon, which is the management of brands among salespeople and consumers when brand interactions are physically less frequent, with an increase in the use of electronic communication channels. 
As job satisfaction increases outcome performance directly and indirectly (mediated by organizational commitment), the results suggest that this construct is central to salesperson performance in small businesses, indicating that managers should measure and plan actions and goals to elevate their levels. Brand attachment and associated job satisfaction should be measured to obtain a time series of measures of these relevant constructs as, according to the results, job satisfaction plays a more relevant role in generating performance. Because of the high level of social interactions in small stores and the reduced number of people involved in the operation, managers should be aware of transforming these interactions into continuous drivers of job satisfaction, which is a temporary evaluation that is dependent on recent experiences within the group.

However, organizational commitment acts as a buffer that ensures performance behaviors under different levels of job satisfaction. Investments to increase organizational commitment are a secure and relevant long-term strategy to be considered by managers, certifying behaviors that are drivers of salesperson performance. As brand attachment and job satisfaction explained $64.1 \%$ of organizational commitment, commitment can be obtained at an adequate level by managing just two constructs. Therefore, the results also reveal how relevant it should be for managers to create dashboards to control, act and plan actions to leverage these elements to increase salesperson performance in small retailing.

\subsection{Limitations and future research}

This research is not exempt from limitations, which can motivate further research. First, the results come from a unique sample of a transversal design study as this is the first study that entails brand attachment and sales performance in retailing. Second, the findings suggest other areas of research concerning the study of salesperson performance. Indeed, one area of future research involves the application of this model in different contexts. Considering that in small retailers, the role of the seller and the degree of involvement with the brand are different when compared to large retailers, a suggestion is to make comparisons between retailers of different sizes. Further research may also involve the testing of this model with a more heterogeneous sample where comparisons with emerging and developed countries could be made.

A second area for further research concerns the application of this model to compare the levels of self-expressiveness of retailer brands and to check for possible differences. Finally, it is suggested that constructs related to classic brand-relationship theory, such as brand love, trust and loyalty, be integrated into the model of this research to increase its capacity to understand and explain the impacts on salesperson performance.

\section{References}

Allen, N.J. and Meyer, J.P. (1990), "The measurement and antecedents of affective, continuance and normative commitment to the organization", Journal of Occupational Psychology, Vol. 63 No. 1, pp. 1-18.

Allison, L., Flaherty, K.E., Jung, J.H. and Washburn, I. (2016), "Salesperson brand attachment: a job demands-resources theory perspective", Journal of Personal Selling and Sales Management, Vol. 36 No. 1, pp. 3-18.

Badrinarayanan, V. and Laverie, D.A. (2011), "Brand advocacy and sales effort by retail salespeople: antecedents and influence of identification with manufacturers' brands", Journal of Personal Selling and Sales Management, Vol. 31 No. 2, pp. 123-140.

Does brandrelationships matter? 
SJME

26,1

Badrinarayanan, V., Ramachandran, I. and Madhavaram, S. (2019), "Mirroring the boss: ethical leadership, emulation intentions, and salesperson performance", Journal of Business Ethics, Vol. 159 No. 3, pp. 897-912.

Bagozzi, R.P. and Yi, Y. (1988), "On the evaluation of structural equation models", Journal of the Academy of Marketing Science, Vol. 16 No. 1, pp. 74-94.

Bagozzi, R.P., Belschak, F., Verbeke, W. and Gavino, J.C. Jr, (2016), "Salesperson Self-Regulation of pride: effects on adaptability, effort, and citizenship behaviors between independentbased and interdependent-based cultures", Spanish Journal of Marketing - Esic, Vol. 20 No. 1, pp. 1-17.

Baldauf, A. and Cravens, D.W. (2002), "The effect of moderators on the salesperson behavior performance and salesperson outcome performance and sales organization effectiveness relationships", European Journal of Marketing, Vol. 36 Nos 11/12, pp. 1367-1388.

Barki, E. and Parente, J. (2010), "Consumer behaviour of the base of the pyramid market in Brazil", Greener Management International, Vol. 56 No. 1, pp. 11-23.

Beeler, L.L. (2017), "Blinded by the Brand: Why and when salesperson Brand attachment decreases customer purchase intentions?”, Doctoral Dissertation, University of Tennessee, Knoxville.

Behrman, D.N. and Perreault, W.D. Jr, (1982), "Measuring the performance of industrial salespersons", Journal of Business Research, Vol. 10 No. 3, pp. 355-370.

Brown, S.P. and Peterson, R.A. (1993), "Antecedents and consequences of salesperson job satisfaction: Meta-analysis and assessment of causal effects", Journal of Marketing Research, Vol. 30 No. 1, pp. 63-77.

Brown, S.P. and Peterson, R.A. (1994), "The effect of effort on sales performance and job satisfaction”, Journal of Marketing, Vol. 58 No. 2, pp. 70-80.

Cepeda, G., Nitzl, C. and Roldán, J.L. (2017), "Mediation analyses in partial least squares structural equation modeling: Guidelines and empirical examples", in Latan, H. and Noonan, R. (Eds), Partial Least Squares Path Modeling: Basic Concepts, Methodological Issues and Applications, Springer, Cham, pp. 173-195.

Churchill, G.A., Ford, N.M., Hartley, S.W. and Walker, O.C. (1985), "The determinants of salespersons performance: a Meta-analysis", Journal of Marketing Research, Vol. 22 No. 2, pp. 103-118.

Cohen, J. (1992), “A power primer”, Psychological Bulletin, Vol. 112 No. 1, pp. 155-159.

Cortiñas, M., Chocarro, R. and Elorz, M. (2019), "Omni-channel users and omni-channel customers: a segmentation analysis using distribution services”, Spanish Journal of Marketing - ESIC, Vol. 23 No. 3, pp. 415-436.

Dennis, C., Papagiannidis, S., Alamanos, E. and Bourlakis, M. (2016), "The role of brand attachment strength in higher education", Journal of Business Research, Vol. 69 No. 8, pp. 3049-3057.

Dijkstra, T.K. and Henseler, J. (2015), “Consistent partial least squares path modelling”, MIS Quarterly, Vol. 39 No. 2, pp. 297-316.

Eliyana, A. and Ma'arif, S. (2019), "Job satisfaction and organizational commitment effect in the transformational leadership towards employee performance", European Research on Management and Business Economics, Vol. 25 No. 1, pp. 144-150.

Fetscherin, M. (2020), The Brand Relationship Playbook, MF, Orlando, FL.

Fornell, C. and Larcker, D.F. (1981), "Evaluating structural equation models with unobservable variables and measurement error", Journal of Marketing Research, Vol. 18 No. 1, pp. 39-50.

Fournier, S. and Alvarez, C. (2012), "Brands as relationship partners: warmth, competence, and inBetween”, Journal of Consumer Psychology, Vol. 22 No. 2, pp. 177-185.

Fu, F.Q., Elliott, M.T., Mano, H. and Galloway, C. (2017), "The role of affective brand commitment on sales effort", Journal of Marketing Theory and Practice, Vol. 25 No. 3, pp. 257-273. 
Gammoh, B.S., Mallin, M.L., Pullins, E.B. and Johnson, C.M. (2018), "The role of salesperson Brand selling confidence in enhancing important sales management outcomes: a social identity approach", Journal of Business and Industrial Marketing, Vol. 33 No. 3, pp. 277-290.

Gerbing, D.W. and Anderson, J.C. (1988), "An updated paradigm for scale development incorporating unidimensionality and its assessment", Journal of Marketing Research, Vol. 25 No. 2, pp. 186-192.

Giacobbe, R.W., Jackson, D.W., Jr, Crosby, L.A. and Bridges, C.M. (2006), “A contingency approach to adaptive selling behavior and sales performance: selling situations and salesperson characteristics", Journal of Personal Selling and Sales Management, Vol. 26 No. 2, pp. 115-142.

Gillespie, E.A. and Noble, S.M. (2017), "Stuck like glue: the formation and consequences of brand attachments among salespeople”, Journal of Personal Selling and Sales Management, Vol. 37 No. 3, pp. 228-249.

Gill-Simmen, L., MacInnis, D.J. and Eisingerich, A.B. (2018), "Brand-self connections and brand prominence as drivers of employee brand attachment”, AMS Review, Vol. 8 Nos 3/4, pp. 128-146, doi: 10.1007/s13162-018-0110-6.

Haenlein, M. and Kaplan, A.M. (2004), "A beginner's guide to partial least squares analysis", Understanding Statistics, Vol. 3 No. 4, pp. 283-297.

Hair, J.F., Anderson, R.E., Tatham, R.L. and Black, W.C. (2006), Multivariate Data Analysis, PrecticeHall, Upper Saddle River, NJ.

Hair, J.F., Hult, G.T.M., Ringle, C. and Sarstedt, M. (2017), A Primer on Partial Least Squares Structural Equation Modeling (PLS-SEM), Sage publications, p. 384.

Henseler, J., Hubona, G. and Ray, P.A. (2016), "Using PLS path modeling in new technology research: updated guidelines”, Industrial Management and Data Systems, Vol. 116 No. 1, pp. 2-20.

Henseler, J., Ringle, C.M. and Sarstedt, M. (2015), "A new criterion for assessing discriminant validity in variance-based structural equation modeling”, Journal of the Academy of Marketing Science, Vol. 43 No. 1, pp. 115-135.

Herjanto, H. and Franklin, D. (2019), "Investigating salesperson performance factors: a systematic review of the literature on the characteristics of effective salespersons", Australasian Marketing Journal, Vol. 27 No. 2, pp. 104-112.

Hu, L.T. and Bentler, P.M. (1999), "Cutoff criteria for fit indexes in covariance structure analysis: conventional criteria versus new alternatives", Structural Equation Modeling: A Multidisciplinary Journal, Vol. 6 No. 1, pp. 1-55.

Hughes, D.E. and Ahearne, M.J. (2010), "Energizing the reseller's sales force: the power of brand identification", Journal of Marketing, Vol. 74 No. 4, pp. 81-96.

Hughes, D.E., Richards, K.A., Calantone, R., Baldus, B. and Spreng, R.A. (2019), "Driving in-Role and Extra-Role Brand performance among retail frontline salespeople: antecedents and the moderating role of customer orientation", Journal of Retailing, Vol. 95 No. 2, pp. 130-143.

IBGE (2020), "Instituto brasileiro de geografia e estatística", available at: https://brasilemsintese.ibge. gov.br/trabalho/ (accessed 20 November 2020).

Investopedia (2020), "Investopedia”, available at: www.investopedia.com/terms/r/retail-sales.asp/ (accessed 10 June 2020).

Jaramillo, F. (2005), "A Meta-analysis of the relationship between organizational commitment and salesperson job performance: 25 years of research”, Journal of Business Research, Vol. 58 No. 6 , pp. 705-714.

Jaramillo, F., Mulki, J.P. and Marshall, G.W. (2005), "A meta-analysis of the relationship between organizational commitment and salesperson job performance: 25 years of research", Journal of Business Research, Vol. 58 No. 6, pp. 705-714. 
SJME

26,1

Jaworski, B.J. and Kohli, A. (1991), "Supervisory feedback: alternative types and their impact on salespeople's performance and satisfaction", Journal of Marketing Research, Vol. 28 No. 2, pp. 190-201.

Judge, T.A., Thoresen, C.J., Bono, J.E. and Patton, K.J. (2001), "The job satisfaction - job performance relationship: a qualitative and quantitative review", Psychological Bulletin, Vol. 127 No. 3, pp. 376-407.

Khusainova, R., de Jong, A., Lee, N., Marshall, G.W. and Rudd, J.M. (2018), “(re) defining salesperson motivation: current status, main challenges, and research directions", Journal of Personal Selling and Sales Management, Vol. 38 No. 1, pp. 2-29.

Kim, C. and Takashima, K. (2019), "Effects of retail organisation design on improving private label merchandising", European Journal of Marketing, Vol. 53 No. 12, pp. 2582-2603.

Kwak, H., Anderson, R.E., Leigh, T.W. and Bonifield, S.D. (2019), "Impact of salesperson macroadaptive selling strategy on job performance and satisfaction", Journal of Business Research, Vol. 94 No. 1, pp. 42-55.

Lenartowicz, T. and Balasubramanian, S. (2009), "Practices and performance of small retail stores in developing economies", Journal of International Marketing, Vol. 17 No. 1, pp. 58-90.

MacInnis, D.J. and Folkes, V.S. (2010), “The disciplinary status of consumer behavior: a sociology of science perspective on key controversies", Journal of Consumer Research, Vol. 36 No. 6, pp. 899-914.

Mallin, M.L., Gammoh, B.S., Pullins, E.B. and Johnson, C.M. (2017), “A new perspective of salesperson motivation and salesforce outcomes: the mediating role of Salesperson-Brand identification", Journal of Marketing Theory and Practice, Vol. 25 No. 4, pp. 357-374.

Meyer, J.P. and Allen, N.J. (1991), "A three-component conceptualization of organizational commitment", Human Resource Management Review, Vol. 1 No. 1, pp. 61-89.

Miao, F., C. and Evans, K.R. (2007), "The impact of salesperson motivation on role perceptions and job performance - a cognitive and affective perspective", Journal of Personal Selling and Sales Management, Vol. 27 No. 1, pp. 89-101.

Michel, G., Merk, M. and Eroglu, S. (2015), "Salespersona-brand relationship: main dimensions and impact within the context of private brand retailing", Journal of Personal Selling and Sales Management, Vol. 35 No. 4, pp. 314-333.

Nanarpuzha, R. and Noronha, E. (2016), "Seeking attention: an investigation of salesperson influence strategies used while selling to small retailers", Journal of Personal Selling and Sales Management, Vol. 36 No. 2, pp. 144-159.

Nitzl, C., Roldan, J.L. and Cepeda, G. (2016), "Mediation analysis in partial least squares path modeling: helping researchers discuss more sophisticated models", Industrial Management and Data Systems, Vol. 116 No. 9, pp. 1849-1864.

Park, C.W., MacInnis, D.J. and Priester, J.R. (2007), "Brand attachment and management of a strategic Brand exemplar", in Schmitt, B.H. (Ed.), Handbook of Brand and Experience Management, Elgar Publishing.

Park, C.W., MacInnis, D.J., Priester, J., Eisingerich, A.B. and Iacobucci, D. (2010), "Brand attachment and brand attitude strength: conceptual and empirical differentiation of two critical brand equity drivers", Journal of Marketing, Vol. 74 No. 6, pp. 1-17.

Peterson, R.A. (2020), "Self-efficacy and personal selling: review and examination with an emphasis on sales performance", Journal of Personal Selling and Sales Management, Vol. 40 No. 1, pp. 57-71.

Podsakoff, P.M. and Organ, D.W. (1986), "Self-Reports in organizational research: Problems and prospects", Journal of Management, Vol. 12 No. 4, pp. 531-544.

Prajapati, B. Dunne, M. and Armstrong, R. (2010), "Sample size estimation and statistical power analyses", Ot PeerReviewed, available at: https:/pdfs.semanticscholar.org/0fa6/ a64d909705403f50a184554d93938a4cade3.pdf 
Rafiei, M., Amini, M. and Foroozandeh, N. (2014), "Studying the impact of the organizational commitment on the job performance", Management Science Letters, Vol. 4 No. 8, pp. 1841-1848.

Raut, U.R., Pawar, P.A., Brito, P.Q. and Sisodia, G.S. (2019), "Mediating model of brand equity and its application", Spanish Journal of Marketing - ESIC, Vol. 23 No. 2, pp. 295-318.

Rigdon, E.E. (2016), "Choosing PLS path modeling as analytical method in European management research: a realist perspective", European Management Journal, Vol. 34 No. 6, pp. 598-605.

Ringle, C., Da Silva, D. and Bido, D. (2015), "Structural equation modeling with the SmartPLS", Brazilian Journal of Marketing, Vol. 13 No. 2, pp. 56-73.

Rukmana, D. (2014), "Quota sampling”, in Michalos A.C. (Ed.), Encyclopedia of Quality of Life and WellBeing Research, Springer, Dordrecht

Rutherford, B.N., Boles, J.S. and Ambrose, S.C. (2019), "Reconceptualizing the measurement of multidimensional salesperson job satisfaction", Journal of Personal Selling and Sales Management, Vol. 39 No. 3, pp. 287-298.

SBA - US Small Business Administration (2019), "Small business profile", available at https://cdn. advocacy.sba.gov/wp-content/uploads/2019/04/23142610/2019-Small-Business-Profiles-StatesTerritories.pdf/ (accessed 16 October 2020).

Schrock, W.A., Hughes, D.E., Fu, F.Q., Richards, K.A. and Jones, E. (2016), "Better together: trait competitiveness and competitive psychological climate as antecedents of salesperson organizational commitment and sales performance”, Marketing Letters, Vol. 27 No. 2, pp. 351-360.

Schwepker, C.H. Jr, (2019), "Using ethical leadership to improve Business-To-Business salesperson performance: the mediating roles of trust in manager and ethical ambiguity", Journal of Business-to-Business Marketing, Vol. 26 No. 2, pp. 141-158.

SEBRAE - Serviço Brasileiro de Apoio às Micro e Pequenas Empresas (2020), available at https://m.sebrae. com.br/sites/PortalSebrae/ufs/sp/sebraeaz/pequenos-negocios-em-numeros,12e8794363447510VgnVC M1000004c00210aRCRD/ (accessed 20 November 2020).

Sepulcri, L.M.C.B., Mainardes, E.W. and Marchiori, D.M. (2020), "Brand orientation: a systematic literature review and research agenda", Spanish Journal of Marketing - ESIC, Vol. 24 No. 1, pp. 97-113.

Siong, Z.M.B., Mellor, D., Moore, K.A. and Firth, L. (2006), "Predicting intention to quit in the call Centre industry: does the retail model fit?", Journal of Managerial Psychology, Vol. 21 No. 3, pp. 231-243.

Sirianni, N.J., Bitner, M.J., Brown, S.W. and Mandel, N. (2013), "Branded service encounters: Strategically aligning employee behavior with the Brand positioning", Journal of Marketing, Vol. 77 No. 6, pp. 108-123.

SmartPLS ${ }^{a}$ (2021), "Fit measures in SmartPLS", available at www.smartpls.com/documentation/ algorithms-and-techniques/model-fit; (accessed 26 January 2021).

SmartPLS ${ }^{b}$ (2021), "Mediation in PLS-SEM", available at www.smartpls.com/documentation/ algorithms-and-techniques/mediation; (accessed 27 January 2021).

Spiro, R.L. and Weitz, B.A. (1990), "Adaptive selling: conceptualization, measurement, and nomological valid-ity”, Journal of Marketing Research, Vol. 27 No. 1, pp. 61-69.

Sreejesh, S. Dr. (2014), “Consumers' attitudinal and behavioural ties with brands- na integrative approach to build a Consumer-Brand relationship model”, Journal of Research for Consumers, Vol. 26, pp. 32-75.

Sujan, H., Weitz, B.A. and Kumar, N. (1994), "Learning orientation, working smart, and effective selling”, Journal of Marketing, Vol. 58 No. 3, pp. 39-52.

Tabachnick, B.G. and Fidell, L.S. (2007), Using Multivariate Statistics, 5th ed., Boston, Pearson/Allyn and Bacon.

Does brandrelationships matter? 
SJME

26,1
Theodosiou, M. and Katsikea, E. (2007), "How management control and job-related characteristics influence the performance of export sales managers", Journal of Business Research, Vol. 60 No. 12, pp. 1261-1271.

Thomson, M., MacInnis, D. and Park, C.W. (2005), "The ties that bind: measuring the strength of consumers' emotional attachments to brands", Journal of Consumer Psychology, Vol. 15 No. 1, pp. 77-91.

Tsai, S. (2011), "Fostering international brand loyalty through committed and attached relationships", International Business Review, Vol. 20 No. 5, pp. 521-534.

Udayana, I.B.N., Farida, N. and Ardyan, E. (2019), "Selling relationship quality to increase salesperson performance in the pharmacy industry", International Journal of Services and Operations Management, Vol. 33 No. 2, pp. 262-285.

Veloutsou, C. and Delgado-Ballester, E. (2018), "New challenges in Brand management", Spanish Journal of Marketing - ESIC, Vol. 22 No. 3, pp. 254-271.

Verbeke, W., Dietz, B. and Verwaal, E. (2011), "Drivers of sales performance: a contemporary Metaanalysis. have salespeople become knowledge brokers?", Journal of the Academy of Marketing Science, Vol. 39 No. 3, pp. 407-428. 


\begin{tabular}{llll}
\hline Construct/items & $\lambda$ & $t$-Value \\
\hline
\end{tabular}

Brand attachment (MacInnis, Park and Priester 2009) $-\alpha=0.93$,

$\mathrm{AVE}=0.67, \mathrm{CR}=0.94$

To what extent do you feel that (brand name) is part of you?

To what extent do you feel that you are personally connected to (brand name)?

To what extent do you feel that you are emotionally bonded to (brand

0.8838

57.151 name)?

To what extent is (brand name) a part of you and who you are?

To what extent does (brand name) reflect the values you personally

0.8670

0.7951

24.901 cherish?

0.8573

29.950

To what extent are your thoughts and feelings toward (brand name) often

0.8181

18.019

automatic, coming to mind seemingly on their own?

To what extent does the word (brand name) automatically evoke many

0.7297

thoughts about the past, present and future?

To what extent, do your thoughts and feelings toward (brand name) come

0.8049

them?

To what extent do you have many thoughts about (brand name)? To what

naturally and instantly?

Organizational commitment (Allen and Meyer's scale, 1990) $-\alpha=0.67$,

$\mathrm{AVE}=0.60, \mathrm{CR}=0.82$

I am happy to belong to this organization

0.7961

21.126

I feel "emotionally attached" to this organization

This organization has a great deal of personal meaning for me

Brand-selling effort (Sujan et al., 1994) $-\alpha=0.65, \mathrm{AVE}=0.74, \mathrm{CR}=0.85$

0.7967

22.341

0.7381

13.191

I work long hours to meet my sales objectives for the (the brand) (excluded

0.4383

3.2186

because of low loading)

I do not give up easily when I encounter a difficult customer for (the brand)

I work untiringly at selling a customer (the brand) until I get an order for

the (the brand)

Motivation to sell (Spiro and Weitz, 1990) $-\alpha=0.75$, AVE $=0.57, \mathrm{CR}=0.84$

Selling X brand is even more fun than selling products of other brands

Selling $\mathrm{X}$ brand to customers is even more like playing a game than selling the products of other brands

Selling X brand to customers is more exciting and challenging than selling the products of other brands

I prefer the challenge for selling $\mathrm{X}$ brand than for selling other brands

Job satisfaction (Arnold et al., 2009) $-\alpha=0.90, \mathrm{AVE}=0.72, \mathrm{CR}=0.93$

My work gives a sense of accomplishment

0.8489

17.168

0.8457

20.805

My job is exciting

My work is satisfying

Behavioral performance (Behrman and Perreault, 1982) $-\alpha=0.88$,

$\mathrm{AVE}=0.75, \mathrm{CR}=0.92$

I am very effective in maintaining good customer relations

0.8143

19.548

0.7028

12.400

0.8301

25.433

$0.6802 \quad 10.772$

$0.8568 \quad 25.821$

0.8124

22.732

0.8252

26.395

I am very effective in providing accurate information to customers and 
SJME

26,1

Construct/items

$\lambda$

$t$-Value

I am very effective in providing accurate and complete paperwork

0.8480

21.710

I am very effective in acquiring the necessary knowledge about my

0.8690

22.890

products, competitor's products and my customers' needs

Outcome performance (Behrman and Perreault, 1982) $-\alpha=0.84$,

144

$\mathrm{AVE}=0.68, \mathrm{CR}=0.89$

I am very effective in contributing to my firm's market share

0.8527

0.8372

21.863

I am very effective in generating a high level of dollar sales

0.7986

16.685

I am very effective in selling to major accounts

14.984

Table A1.

Notes: $\mathrm{AVE}=$ average variance extracted; $\mathrm{CR}=$ composite reliability; $\mathrm{SRMR}=0.0839 ; \chi^{2}=1,815.9488$

\section{Corresponding author}

Flavia Braga Chinelato can be contacted at: fchinelato@pucp.edu.pe

For instructions on how to order reprints of this article, please visit our website: www.emeraldgrouppublishing.com/licensing/reprints.htm

Or contact us for further details: permissions@emeraldinsight.com 